\title{
Testing the Sensitivity of Conjunctival Swabs from Confirmed COVID-19 Patients
}

\author{
Manal Hadrawi' \\ Mohammad Malak' \\ Faeeqah Almahmoudi' \\ Ahmed Mogharbel (D) ${ }^{2}$ \\ Omar Rozy' \\ Somaya Hanafi' \\ Batool $\mathrm{Ali}^{3}$ \\ Sanaa Nabeel ${ }^{3}$ \\ Fatimah Faqieha ${ }^{4}$ \\ khaled Alzahrani (iD) \\ 'Department of Ophthalmology, King \\ Fahad Armed Forces Hospital, Jeddah, \\ Saudi Arabia; ${ }^{2}$ Faculty of Medicine, King \\ Abdulalziz University, Jeddah, Saudi \\ Arabia; ${ }^{3}$ Department of Infectious \\ Diseases, East Jeddah Hospital, Ministry \\ of Health, Jeddah, Saudi Arabia; \\ ${ }^{4}$ Department of Public Health, Ministry of \\ Health, Jeddah, Saudi Arabia
}

Objective: To investigate the incidence of COVID-19 viral RNA in the conjunctiva of patients priorly confirmed to have COVID-19, using a conjunctival swab and to determine swab sensitivity.

Methods: This cross-sectional study enrolled patients who tested positive for COVID-19 with PCR via nasopharyngeal swabs. Conjunctival swabs were collected for each patient and subjected to RT-PCR assay. Demographic data and clinical history of patients were investigated and analysed.

Results: In this study, $4.9 \%$ of the patients tested positive with conjunctival swabs for COVID-19; $29.9 \%, 28.7 \%, 20.1 \%$, and $12.2 \%$ of the patients had fever, shortness of breath, cough, and red eye, respectively. Among all patients, $18.9 \%$ and $73.2 \%$ had a history of traveling and contact with positive COVID-19 cases, respectively. There were significant correlations between the conjunctival results and diabetes $(\mathrm{P}=0.049)$ and hypertension $(\mathrm{P}=0.002)$. Traveling was a risk factor for positive conjunctival swab testing $(\mathrm{P}=0.016)$. The sensitivity of the conjunctival swab was $4.8 \%$.

Conclusion: Among all positive cases of COVID-19, a small percentage had positive results when tested using a conjunctival swab. Conjunctival swabs have very low sensitivity for the detection of COVID-19. However, tears could still be a mode of disease transmission, especially from patients to eye care specialists.

Keywords: COVID-19, conjunctival swab, sensitivity, specificity, RNA

\section{Introduction}

In December 2019, China reported a pneumonia outbreak in Wuhan, a city with more than 11 million people, where a local ophthalmologist reported preliminary cases. ${ }^{1}$ Over 55 million people have since been affected in over 210 countries, with over 1.33 million fatalities. The disease represents a global challenge due to limitations in therapeutic options and limited vaccine availability to date. ${ }^{2}$

Individuals infected with COVID-19 can release several respiratory droplets and microscopic particles (bioaerosols) via breath, coughs, sneezes, or speech. These droplets contact the host's ocular and extra-ocular mucus membranes. The virus particle gains entry into the body through interaction with an epithelial cell using its SARS-CoV-2 spike (S) glycoprotein, which binds to the cell membrane protein angiotensin-converting enzyme 2 (ACE2). ${ }^{3,4}$

Fever, headache, cough, shortness of breath, diarrhoea, loss of smell and taste, and malaise are the main symptoms of COVID-19 infection; however, asymptomatic infections have increasingly been reported among populations screened for the disease. ${ }^{5}$
Correspondence: khaled Alzahrani; Ahmed Mogharbel

Department of Ophthalmology, Faculty of Medicine, King Fahad Armed Forces Hospital King Abdulaziz University, Jeddah, Saudi Arabia

Email khaledod@gmail.com;

ahmadmogharbel@gmail.com 
Ocular symptoms range from mild conjunctival injection to acute anterior and posterior uveitis, retinitis, and optic neuritis. The role of the ocular surface as a source of transmission and retrograde transmission has been investigated in several studies and remains an unresolved issue.,

COVID-19 can be transferred through mucous membranes, including the conjunctiva, according to $\mathrm{Lu}$ et al. Many cases have been reported in which ophthalmologists were discovered to be infected during normal diagnosis and treatment. ${ }^{8}$

Given that the virus is present in patients' body fluids, tear fluid is a form of bodily fluid, and SARS- $\mathrm{CoV}=2$ is comparable to SARSCoV, it is possible that tear and conjunctival transmission could occur. ${ }^{9}$

It is debatable whether the virus is present within tears. Xia et al found the presence of COVID-19 within tear film in only one patient with conjunctivitis among persons infected with SARS-CoV-2, using real-time reverse transcription-polymerase chain reaction (RT-PCR) assays. ${ }^{9}$ Seah et al, on the other hand, proposed a low risk of ocular transmission because neither viral culture nor reverse transcription were able to detect viral particles in their tested samples. ${ }^{10}$

Our study aimed to assess the presence of viral RNA within the ocular surface in patients confirmed by pharyngeal swabs to be infected with COVID-19.

\section{Materials and Methods}

This study was conducted in collaboration between the King Fahad Armed Forces Hospital and the Ministry of Health in Jeddah, Saudi Arabia. This study was approved by the Clinical Research Ethics Committee Institutional Review Board (IRB, KACST, KSA, H-02-J-002) and was carried out following the tenets of the Declaration of Helsinki. Informed consent was obtained from all patients.

All patients who were confirmed to have a positive COVID-19 pharyngeal swab and were placed in quarantine in one of the allocated hotels in the period from May 5, 2020 till June 11, 2020 and age were above 18 years were included in our study. Patient demographics and clinical history were noted with respect to COVID-19 symptoms (shortness of breath (SOB), fever, and any other atypical symptoms), the presence of positive contact with a confirmed case, travel and medical history, and history of red eye. The duration of symptoms before taking the swab test was also confirmed as were patient age and sex.
The research team members collected all conjunctival samples from positive cases confirmed by nasopharyngeal swabs.

A well-trained medical doctor, ensuring proper infection control and prevention measures collected each conjunctival swab. The collection of samples started on May 5, 2020 and ended on June 11, 2020. The swabs were collected from both eyes in patients within 1-2 days from subjects who were newly confirmed to be positive based on pharyngeal swabs to make sure only included active viruses. Each conjunctival sample was obtained using a sterile synthetic fibre swab (Flexible Minitip Size Nylon Flocked Swab, Copan Diagnostics, Mantua, Italy) into the inferior fornix without using anaesthesia. A single swab was used to obtain a specimen from each patient's eyes. All precautions were taken to avoid sample contamination and damage. Each swab was immersed in a viral carriage medium (Universal Transport Media; Copan, Italy) and kept at a low temperature before being tested for SARS-CoV-2. RT-qPCR assays were performed at the molecular biology laboratory of KFAFH with qualitative GeneXpert Xpress SARS-CoV-2 (Cepheid, Sunnyvale, CA, USA). The cycle threshold (Ct) was measured.

\section{Statistical Analysis}

Data were analysed using IBM SPSS Statistics for Windows, version 25.0. (Armonk, NY: IBM Corp) and Microsoft Excel (Microsoft Corporation, Redmond, WA, USA). Qualitative data were presented as numbers and percentages. The chi-square test $(\chi 2)$ was used to test the relationship between variables. Quantitative data were presented as mean and standard deviation (mean $\pm \mathrm{SD}$ ). Statistical significance was set at $\mathrm{p}<0.05$.

According to the conjunctival swab sensitivity, truepositive cases (1) comprised 8 cases and 156 were falsenegative cases, and (2) the calculated sensitivity $((\mathrm{a} / \mathrm{a}+\mathrm{b}) \times$ 100) was $4.8 \%$. As there were no false-positive or truenegative cases, the conjunctival swab's specificity could not be calculated.

\section{Results}

One hundred and seventy-one subjects have been recruited for this study. Due to the highly agreement between both eyes, only one eye (RT eye) randomly selected for further analysis. The total swabs samples were valid for analysis were 164 subjects. The main age of the subjects was $34.76 \pm 12.75$ with range of (18-72) year's and male subjects was more 
than female subjects. Our study found that only $4.9 \%$ of conjunctival swabs were positive for COVID-19 (Figure 1).

Table 1 shows that patient mean age was $34.79 \pm 12.78$ years; $61 \%$ were male, and 14\% were smokers. Around $29.9 \%$ had fever, $28.7 \%$ had SOB, 20.1\% had cough, $12.2 \%$ had red eye, and $11.6 \%$ had headache. Patients with diabetes mellitus (DM), hypertension (HT), or asthma comprised 7.3\%, 7.9\%, and 3.7\%, respectively. Among all participants, $18.9 \%$ had travelled outside Saudi Arabia before, and most of them (73.2\%) had previous contact with a positive COVID-19 case. The mean duration of symptom appearance before naseo-pharyngeal swabbing was $5.05 \pm 4.23$ days.

The associations between conjunctival swab results and other variables are shown in Table 2. There was a significantly higher percentage of patients with DM and HT who showed positive results for conjunctival swabs compared with non-diabetic and non-hypertensive patients $(p<0.05)$. On the other hand, a non-significant relationship was found between the other patient characteristics of smoking, asthma, symptoms, traveling outside Saudi Arabia, contact with positive COVID-19 cases, and mean duration of symptom appearance before conjunctival swab and swab results $(\mathrm{p}>0.05)$.

Figure 2 illustrates the percentage of patients who had vomiting and those with history of travel (Figure 3) and shows that a positive conjunctival swab was significantly higher $(p<0.05)$ in these individuals. On the other hand, a non-significant relationship was observed between the presence of red eye and conjunctival swab results $(\mathrm{p}>0.05)$ (Figure 4).

\section{Discussion}

COVID-19 is a novel coronavirus that replicates in the upper respiratory system, making it the primary port of entry and site of infection. ${ }^{3}$ It was reported that the ocular surface could also act as an entry pathway for COVID-19 and that ocular discharges could play a role in the shedding of the virus. ${ }^{3}$ Several reports have suggested that the eyes can be affected at any stage of the disease. ${ }^{11-13}$ A review article stated that positive COVID-19 results in eye specimens were found with a low incidence. ${ }^{14}$

A study from China investigated the presence of COVID-19 in the tears and conjunctival secretions of 30 patients with COVID-19. The study revealed that only two samples of conjunctival secretions and tears were positive for COVID-19, whereas the other samples were negative. The authors suggested that COVID-19 might be detected in conjunctival secretions and tears. However, its incidence is low. ${ }^{9}$

Xia et al analyzed the conjunctival samples of 30 infected patients for SARSCoV-2 RNA, and one patient's conjunctival samples were positive for the virus 3 days later. ${ }^{9}$ Seah et al, on the other hand, found no evidence of SARS-CoV-2 shedding in tears during the disease's course, implying a low risk of ocular transmission. ${ }^{10}$ Conjunctival sampling, according to Chen et al may not

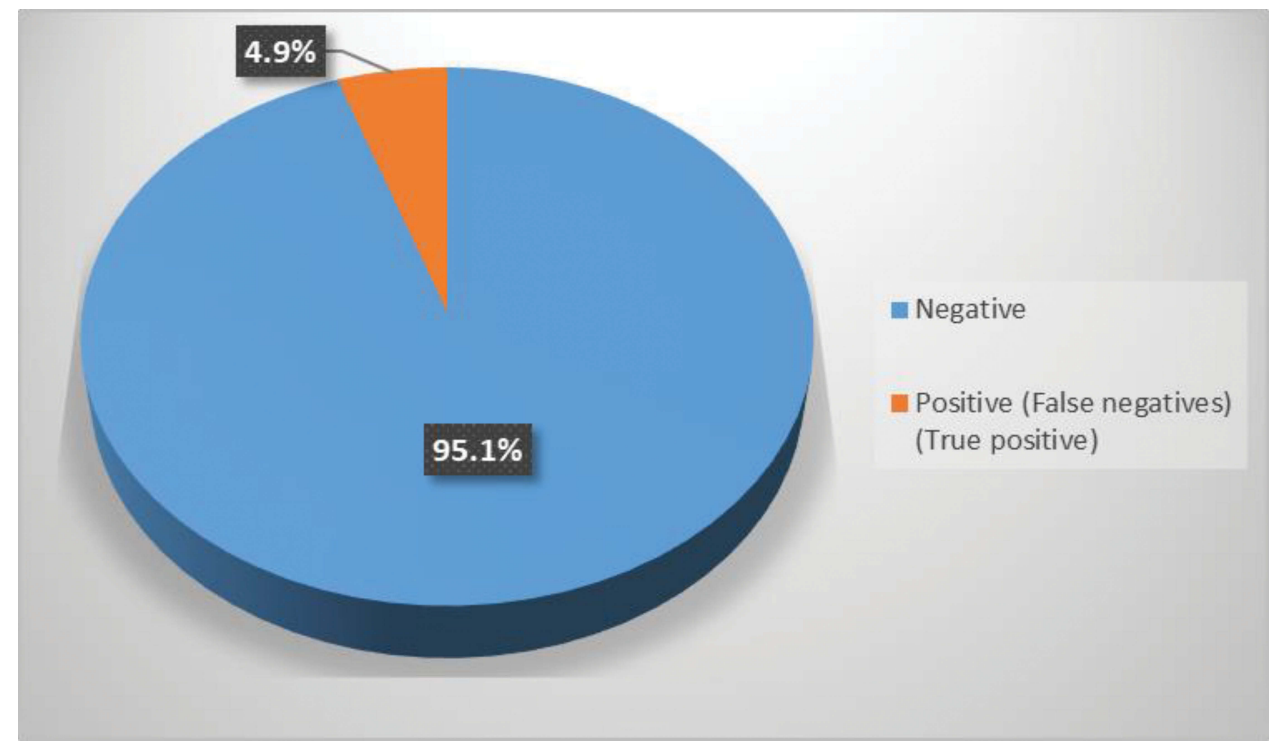

Figure I Percentage distribution of studied patients according to the results of conjunctival swab testing. 
Table I Percentage Distribution of Variables

\begin{tabular}{|c|c|}
\hline Variable & No. (\%) \\
\hline Gender & \\
\hline Female & 64 (39) \\
\hline Male & $100(6 I)$ \\
\hline Smoking & \\
\hline No & $|4|(86)$ \\
\hline Yes & $23(14)$ \\
\hline Fever & \\
\hline No & II $15(70.1)$ \\
\hline Yes & 49 (29.9) \\
\hline SOB & \\
\hline No & 117 (7I.3) \\
\hline Yes & 47 (28.7) \\
\hline Cough & \\
\hline No & |3| (79.9) \\
\hline Yes & $33(20.1)$ \\
\hline Red eye & \\
\hline No & I 44 (87.8) \\
\hline Yes & $20(12.2)$ \\
\hline DM & \\
\hline Yes & $12(7.3)$ \\
\hline No & $152(92.7)$ \\
\hline HT & \\
\hline Yes & $13(7.9)$ \\
\hline No & $151(92.1)$ \\
\hline Asthma & \\
\hline Yes & $6(3.7)$ \\
\hline No & $158(96.3)$ \\
\hline Other symptoms & \\
\hline Anosmia & $8(4.9)$ \\
\hline Dizziness & I $(0.6)$ \\
\hline Headache & $19(11.6)$ \\
\hline IBS & $3(1.8)$ \\
\hline Malaise & $12(7.3)$ \\
\hline Nausea & I (0.6) \\
\hline Sputum & I $(0.6)$ \\
\hline Vomiting & I $(0.6)$ \\
\hline Travelling & \\
\hline No & $133(8 \mathrm{I} .1)$ \\
\hline Yes & 31 (18.9) \\
\hline Contact with positive COVID-19 cases & \\
\hline No & $44(26.8)$ \\
\hline Yes & $120(73.2)$ \\
\hline $\begin{array}{l}\text { Duration of symptoms appearance prior to } \\
\text { swabs taken }\end{array}$ & $5.05 \pm 4.23$ \\
\hline
\end{tabular}

Abbreviations: $\mathrm{SOB}$, shortness of breath; DM, diabetes mellitus; $\mathrm{HT}$, hypertension; IBS, Irritable Bowel Syndrome
Table 2 Association Between Swab Results and Other Variables

\begin{tabular}{|c|c|c|c|c|}
\hline \multirow[t]{2}{*}{ Variable } & \multicolumn{2}{|c|}{ Conjunctival Swabs Results } & \multirow[t]{2}{*}{$\chi^{2}$} & \multirow[t]{2}{*}{ p-value } \\
\hline & $\begin{array}{l}\text { Positive } \\
\text { No. (\%) }\end{array}$ & $\begin{array}{l}\text { Negative } \\
\text { No. (\%) }\end{array}$ & & \\
\hline Age & $43.88 \pm 16.95$ & $35.09 \pm 12.04$ & 1.52 & 0.128 \\
\hline $\begin{array}{l}\text { Gender } \\
\text { Female } \\
\text { Male }\end{array}$ & $\begin{array}{l}2(3.1) \\
6(6)\end{array}$ & $\begin{array}{l}62(96.9) \\
94(94.1)\end{array}$ & 0.69 & 0.44 \\
\hline $\begin{array}{l}\text { Smoking } \\
\text { No } \\
\text { Yes }\end{array}$ & $\begin{array}{l}6(4.3) \\
2(8.7)\end{array}$ & $\begin{array}{l}135 \text { (95.7) } \\
2 \mid(9 \mid .3)\end{array}$ & 0.84 & 0.359 \\
\hline $\begin{array}{l}\text { Fever } \\
\text { No } \\
\text { Yes }\end{array}$ & $\begin{array}{l}6(5.2) \\
2(4.1)\end{array}$ & $\begin{array}{l}109(94.8) \\
48(96)\end{array}$ & 0.09 & 0.757 \\
\hline $\begin{array}{l}\text { SOB } \\
\text { No } \\
\text { Yes }\end{array}$ & $\begin{array}{l}6(5.1) \\
2(4.3)\end{array}$ & $\begin{array}{l}\text { II I (94.9) } \\
45(95.7)\end{array}$ & 0.05 & 0.814 \\
\hline $\begin{array}{l}\text { Cough } \\
\text { No } \\
\text { Yes }\end{array}$ & $\begin{array}{l}5(3.8) \\
3(9.1)\end{array}$ & $\begin{array}{l}126(96.2) \\
30(90.9)\end{array}$ & 1.58 & 0.209 \\
\hline $\begin{array}{l}\text { DM } \\
\text { Yes } \\
\text { No }\end{array}$ & $\begin{array}{l}2(16.7) \\
6(3.9)\end{array}$ & $\begin{array}{l}10(83.3) \\
146(96.1)\end{array}$ & 3.87 & 0.049 \\
\hline $\begin{array}{l}\text { HTN } \\
\text { Yes } \\
\text { No }\end{array}$ & $\begin{array}{l}3(23.1) \\
5(3.3)\end{array}$ & $\begin{array}{l}10(76.9) \\
146(96.1)\end{array}$ & 10.07 & 0.002 \\
\hline $\begin{array}{l}\text { Asthma } \\
\text { Yes } \\
\text { No }\end{array}$ & $\begin{array}{l}0(0.0) \\
8(5.1)\end{array}$ & $\begin{array}{l}6(100) \\
150(94.9)\end{array}$ & 0.31 & 0.572 \\
\hline $\begin{array}{l}\text { Contact with } \\
\text { positive COVID- } \\
19 \text { cases } \\
\text { No } \\
\text { Yes }\end{array}$ & $\begin{array}{l}3(6.8) \\
5(4.2)\end{array}$ & $\begin{array}{l}41 \text { (93.2) } \\
115(95.8)\end{array}$ & 0.48 & 0.485 \\
\hline $\begin{array}{l}\text { Duration of } \\
\text { symptoms } \\
\text { appearance prior } \\
\text { to swabs taken }\end{array}$ & $6.88 \pm 6.46$ & $4.96 \pm 4.09$ & 0.51 & 0.604 \\
\hline
\end{tabular}

Abbreviations: SOB, shortness of breath; DM, diabetes mellitus; $\mathrm{HT}$, hypertension

be effective for early diagnosis since the virus may not emerge in the conjunctiva at all. ${ }^{14}$ However, Colavita et al, as mentioned in our study, revealed a case of conjunctival swab positivity with concurrent nasopharyngeal swab (NFs) negativity, implying a new potential for falsenegative patients. ${ }^{15}$ 


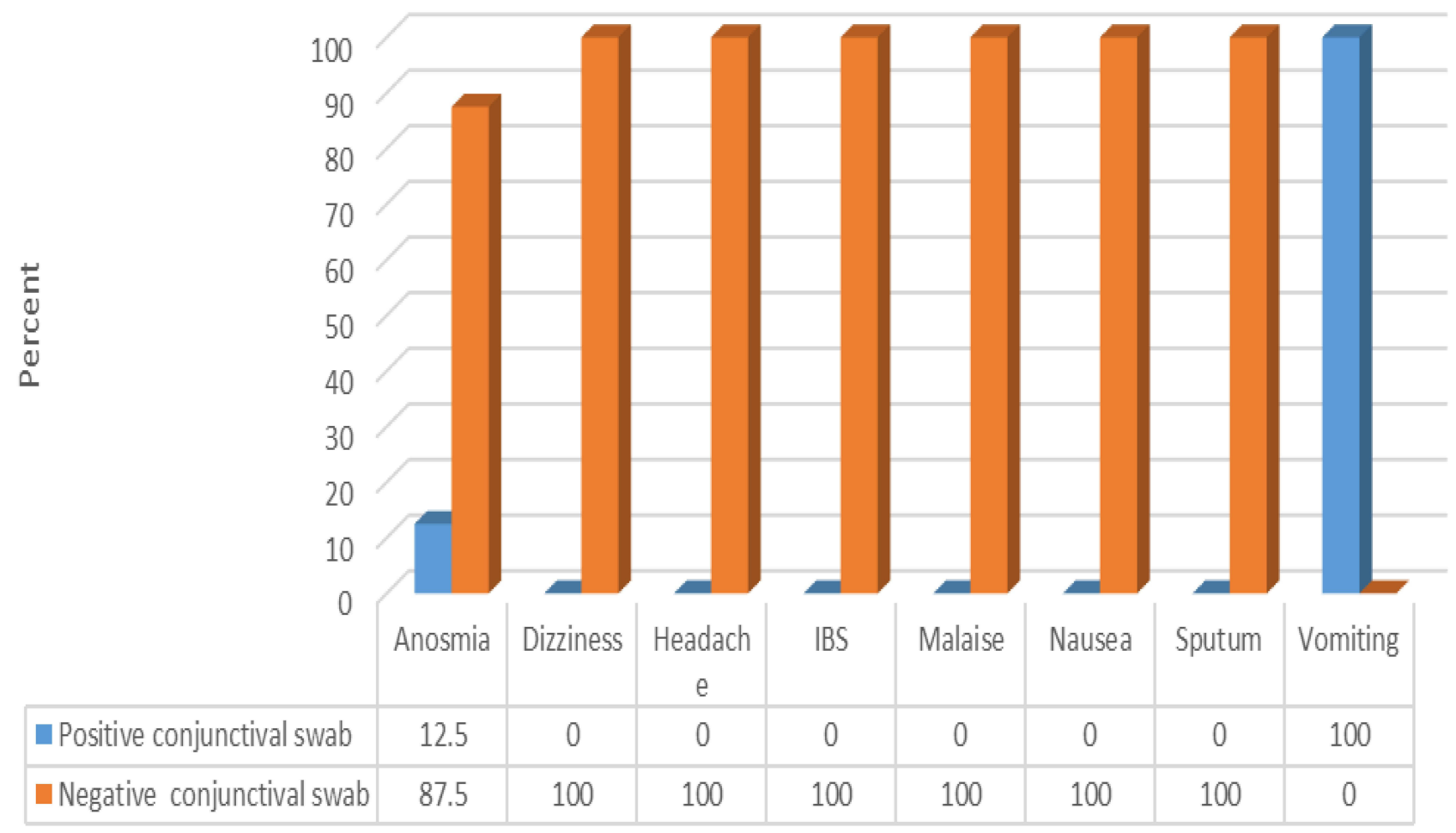

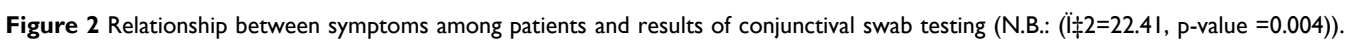

A study from Egypt was conducted to evaluate the incidence of COVID-19 in the tears and conjunctival secretions of patients with confirmed COVID-19. The study reported that COVID-19 was found in the secretions of $28.57 \%$ of the patients, whereas the majority showed negative results. ${ }^{16}$
A study from India by Kumar et $a{ }^{17}$ was conducted for the same purpose as the previous two studies by Xia et al and Mahmoud et al. ${ }^{9,16}$ The Indian study included 45 COVID-19 patients who underwent conjunctival swabs for the RT-PCR assay. The study revealed that only

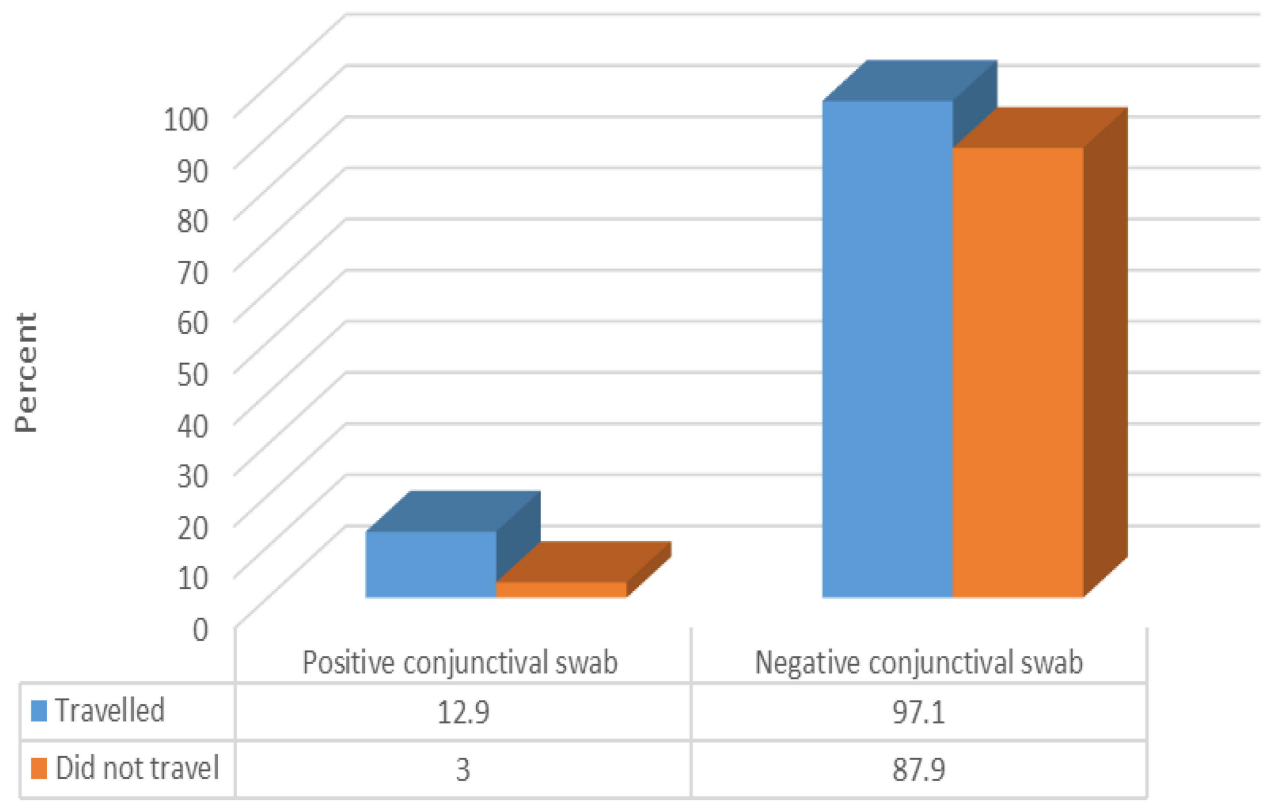

Figure 3 Relationship between previous travel and results of conjunctival swab testing (N.B.: $(\chi 2=5.3, p$-value $=0.021)$ ). 


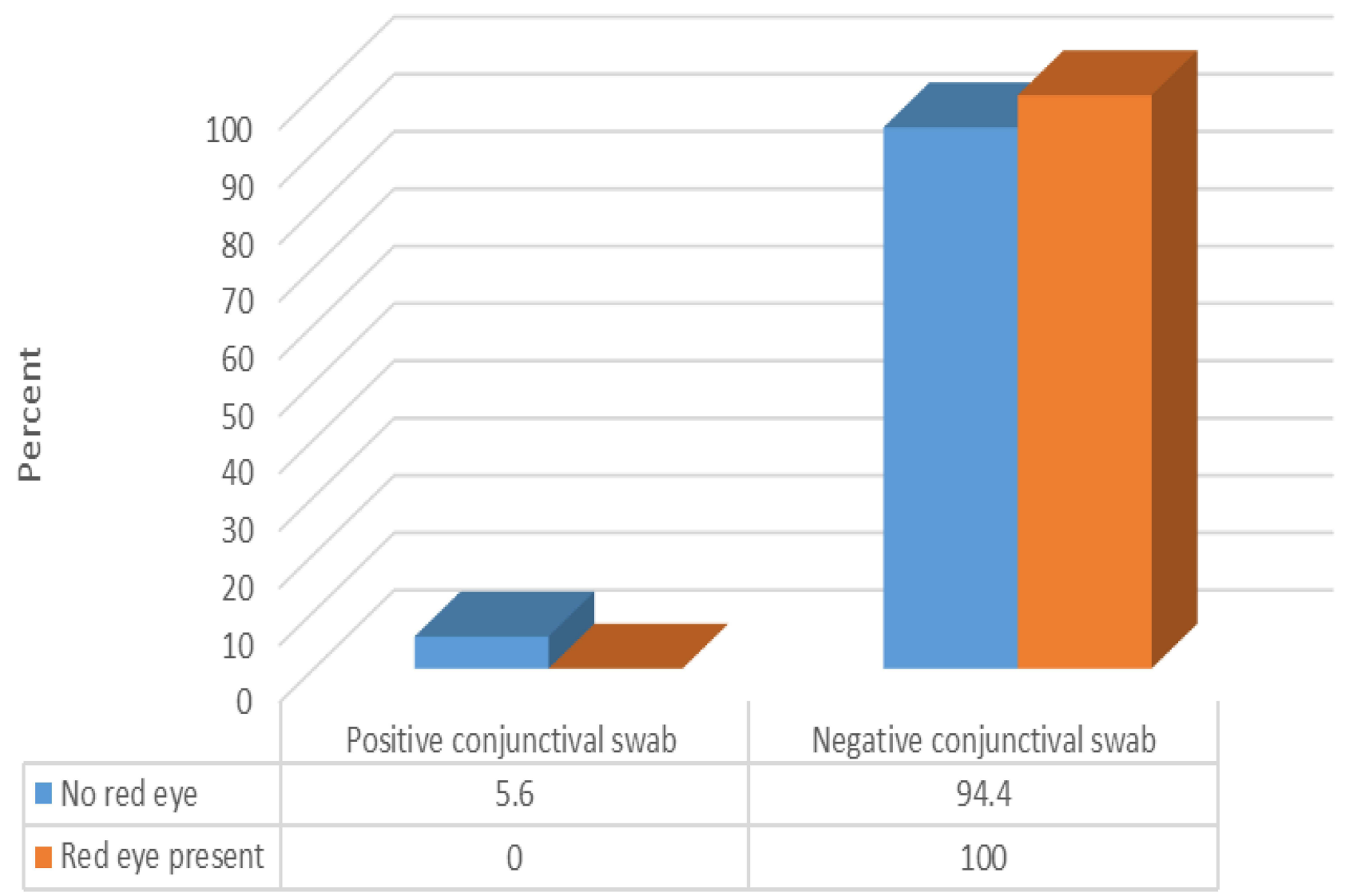

Figure 4 Relationship between presence of red eye and results of conjunctival swab testing (N.B.: (Ï $\neq 2=I .16, p-v a l u e=0.28)$ ).

$2.23 \%$ of 45 COVID-19 patients were positive for RT-PCR COVID-19 from conjunctival swabs. ${ }^{17}$ Another study enrolled 46 patients confirmed with COVID-19 through the nasopharyngeal swab; only $8.2 \%$ of them were found to be COVID-19 positive using conjunctival swabs. ${ }^{18}$

We are unaware of any previous study conducted in Saudi Arabia populations that has investigated the role of conjunctival swabs in detecting COVID-19 cases; therefore, we conducted this study. In this study, only $4.9 \%$ of the patients had positive COVID-19 results using conjunctival swabs for RT-PCR assay, although all patients were positive for COVID-19 as found by nasopharyngeal swabs. The findings of this study were in agreement with those of previous studies. ${ }^{9,16-18}$

Several demographics and clinical characteristics of patients were investigated to assess whether any clinical characteristics or patient history data could be associated with the positive results obtained with a conjunctival swab. Our study comprised more male participants than females, and the majority of the patients were nonsmokers. A few patients experienced fever, SOB, cough, and red eyes. However, none of these factors was significantly associated with the conjunctival swab results.

Previous studies have found that patients' ocular symptoms can be modest and self-healing, therefore many COVID-19 patients may not bother to report them. As a result, symptoms may appear in either the early or late stages of the disease. ${ }^{13,14}$

In relation to chronic diseases, a very small percentage of our sample had DM, HT, or asthma. Only DM and HT were found to significantly affect conjunctival swab findings. A history of travel was not common, whereas a large percentage of patients reported contact with COVID-19 cases. However, those who reported recent traveling history (outside Saudi Arabia) were more likely to show positive results through the conjunctival swab. Hence, traveling from area with high-infected cases with COVID-19 is a risk factor for a positive conjunctival swab test results. That is why, in patients with recent travel who report with acute conjunctivitis, COVID-19 should be considered as one of the differential diagnosis as recommended by previous studies. ${ }^{19,20}$ 
Similarly, one of the previews study reported that fever, cough, and conjunctivitis were prevalent among a few patients with confirmed COVID-19. Either those with positive COVID-19 conjunctival secretions were with or without conjunctivitis; therefore, conjunctivitis had no association with the conjunctival swab results. ${ }^{16}$

Positive conjunctival swab samples were found in 3/ 121 patients by Zhou et al two of whom did not exhibit ocular symptoms. ${ }^{13}$ SARSCoV-2 RNA was found in conjunctival specimens of 2/27 COVID-19 patients without conjunctivitis, according to $\mathrm{Ye}$ et al. ${ }^{21} \mathrm{Hu}$ et al described a 70-year-old COVID-19 patient who had a history of common lacrimal duct obstruction in his left eye but no conjunctivitis. $^{22}$

Although many other studies have reported the incidence of COVID-19 RNA in conjunctival swabs. In this study, we investigated the sensitivity of such swabs and found that the sensitivity was only $4.8 \%$. In contrast, the specificity could not be calculated owing to the findings from the samples. This finding agrees with a meta-analysis study that concludes very low sensitivity of conjunctival swabs in comparison to pharyngeal one (Ulhaq and Soraya, 0.2020). ${ }^{23}$

Generally, the significant rate finding of the COVID-19 RNA in the conjunctival swabs could be due to some reasons as the low sensitivity of the test. Detecting the virus from conjunctive due to viral load in the eye not reach the minimum threshold to be detected as in positive patients confirmed through nasopharyngeal swabs. ${ }^{14,24}$ It is possible the viruses appear for short period in the eye, which may need specific and precise collection time. ${ }^{9,15,25}$

Telemedicine sorted some issues of patient management but it is considers limited in eye care due to the service nature. Even with considers reducing and limited number of patients visiting eye care centres still there are a lot of patients need face-to-face clinical care. ${ }^{26}$ Those patients visiting eye care centres, if they are infected, can release a bio-aerosol droplets when they are sneezing or coughing or talking if they are not using masks. Safety of the eye care provider is very important and that is considered implemented in full PPE. Eye care provider considers to be more supposed to be infected with coronaviruses due to close contact to the patients during daily work activities and surgical procedures. Slit-lamp breath shields, hand, hygiene, facial masks, reducing patients talking when he is under examination, use of eye protection and considers disinfected all the equipment between the patients are very crucial in reduce corona viruses transmissions. ${ }^{27,28}$

Even if our study was not supporting the presence of corona viruses in the eye, it is still important to consider patient visit to the eye care centres as the source of infection and disease spared.

Previous studies demonstrated the controversial data concerning the different percentages of positive results for SARS-CoV-2 in tear samples from COVID-19 patients. Most of these studies did not report/investigate the use of eye drops by these patients. However, many ophthalmic medications have antiviral action that could be a confounding factor causing potential bias.

This study was limited by a small sample size and the period between nasopharyngeal and conjunctival swab sampling. Our results could have also been affected by the sensitivity of the PCR test itself.

In conclusion, this study showed that the RNA of COVID-19 could be present in tears with a low incidence. The high correlation between DM and the positive presence of the virus in conjunctival swabs suggested that patients with DM are at risk of contracting COVID-19 infections in comparison with other diseases. The conjunctival swab had low sensitivity; nevertheless, COVID-19 was found in tears, making them a possible media for transmission.

\section{Acknowledgments}

The authors thank the King Fahad Armed Forces Hospital and the Head of the Molecular Laboratory Mr Abdalwahab Alzahrani,Mr Waheed Alsahali and their colleagues for their great support in sample analysis. We would also like to thank Dr. Nuha Dashash, a member of the Saudi Ministry of Health-Jeddah Region, for supporting patient recruitment for this study. This study was supported by the Armed Forces Medical Services, Ministry of Defense, Riyadh, Saudi Arabia.

\section{Disclosure}

None of the authors have any proprietary interests or conflicts related to this submission.

\section{References}

1. Bozkurt B, Eğrilmez S, Şengör T, Yıldırım Ö, Irkeç M. The COVID-19 pandemic: clinical information for ophthalmologists. Turk J Ophthalmol. 2020;50(2):59-63. doi:10.4274/tjo.galenos.2020.29805

2. Zou P, Huo D, Li M. The impact of the COVID- 19 pandemic on firms: a survey in Guangdong Province, China. Glob Health Res Policy. 2020;5:41. doi:10.1186/s41256-020-00166-z 
3. Kharel Sitaula R, Khatri A, Janani MK, et al. Unfolding COVID-19: lessons-in-learning in ophthalmology. Clin Ophthalmol. 2020;14:2807-2820. doi:10.2147/OPTH.S259857

4. Dawood AA. Transmission of SARS CoV-2 virus through the ocular mucosa worth taking precautions. Vacunas (English Edition). 2021;22:56-57. doi:10.1016/j.vacune.2021.01.007

5. Yuan H, Chan Y, Xin-Feng X, Wei X, Shu-Wen L. Structural and functional properties of SARS-CoV-2 spike protein: potential antiviral drug development for COVID-19. Acta Pharmacol Sin. 2020;41:1141-1149. doi:10.1038/s41401-020-0485-4

6. Ho D, Low R, Tong L, Gupta V, Veeraraghavan A, Agrawal RCOVID-19. and the ocular surface: a review of transmission and manifestations. Ocul Immunol Inflamm. 2020;28:726-734. doi:10.1080/09273948.2020.1772313

7. Hu K, Patel J, Patel BC. 2021. Ophthalmic manifestations of coronavirus (COVID-19). In: Abai B, Abu-Ghosh A, editors. StatPearls. Treasure Island, FL: StatPearls Publishing. Available from https:// www.ncbi.nlm.nih.gov/books/NBK556093. Accessed June 4, 2021.

8. Lu CW, Liu XF, Jia ZF. 2019-nCoV transmission through the ocular surface must not be ignored. Lancet. 2020;395:e39. doi:10.1016/ S0140-6736(20)30313-5

9. Xia J, Tong J, Liu M, Shen Y, Guo D. Evaluation of coronavirus in tears and conjunctival secretions of patients with SARSCoV-2 infection. J Med Virol. 2020;92:589-594. doi:10.1002/jmv.25725

10. Seah IYJ, Anderson DE, Kang AEZ, et al. Assessing viral shedding and infectivity of tears in coronavirus disease 2019 (COVID-19) patients. Ophthalmology. 2020;127:977-979. doi:10.1016/j. ophtha.2020.03.026

11. Wu P, Duan F, Luo C, et al. Characteristics of ocular findings of patients with coronavirus disease 2019 (COVID-19) in Hubei Province, China. JAMA Ophthalmol. 2020;138:575-578. doi:10.1001/jamaophthalmol.2020.1291

12. Zhang X, Chen X, Chen L, et al. The evidence of SARS-CoV-2 infection on ocular surface. Ocul Surf. 2020;18:360-362. doi:10.1016/j.tos.2020.03.010

13. Zhou Y, Zeng Y, Tong Y, Chen C. Ophthalmologic evidence against the interpersonal transmission of 2019 novel coronavirus through conjunctiva. medRxiv. 2020;20021956. doi:10.1101/ 2020.02.11.20021956

14. Chen L, Liu M, Zhang Z, et al. Ocular manifestations of a hospitalised patient with confirmed 2019 novel coronavirus disease. Br J Ophthalmol. 2020;104(6):748-751.

15. Colavita F, Lapa D, Carletti F, et al. SARSCoV-2 isolation from ocular secretions of a patient with COVID-19 in Italy with prolonged viral RNA detection. Ann Intern Med. 2020;173:242-243. doi:10.7326/M20-1176

16. Mahmoud H, Ammar H, El Rashidy A, Ali AH, Hefny HM, Mounir A. Assessment of coronavirus in the conjunctival tears and secretions in patients with SARS-CoV-2 infection in Sohag Province, Egypt. Clin Ophthalmol (Auckland, NZ). 2020;14:2701-2708. doi:10.2147/OPTH.S270006
17. Kumar K, Prakash AA, Gangasagara SB, et al. Presence of viral RNA of SARS-CoV-2 in conjunctival swab specimens of COVID-19 patients. Indian $J$ Ophthalmol. 2020;68:1015-1017. doi:10.4103/ijo.IJO_1287_20

18. Li X, Chan JF, Li KK, et al. Detection of SARS-CoV-2 in conjunctival secretions from patients without ocular symptoms. Infection. 2020:1-9. doi:10.1007/s15010-020-01524-2.

19. Cheema M, Aghazadeh H, Nazarali S, et al. Keratoconjunctivitis as the initial medical presentation of the novel coronavirus disease 2019 (COVID-19). Can J Ophthalmol. 2020;55:e125-9.

20. Khavandi S, Tabibzadeh E, Naderan M, Shoar S. Corona virus disease-19 (COVID-19) presenting as conjunctivitis: atypically high-risk during a pandemic. Cont Lens Anterior Eye. 2020;43:211-212.

21. Ye Y, Song Y, Yan M, et al. Novel coronavirus pneumonia combined with conjunctivitis: three cases report. Chin J Exp Ophthalmol. 2020;38:242-244. doi:10.3760/cma.j.issn.2095-0160.2020.0006

22. Hu Y, Chen T, Liu M, et al. Positive detection of SARS- CoV-2 combined HSV1 and HHV6B virus nucleic acid in tear and conjunctival secretions of a non-conjunctivitis COVID-19 patient with obstruction of common lacrimal duct. Acta Ophthalmol. 2020. doi:10.1111/aos. 14456

23. Ulhaq ZS, Soraya GV. The prevalence of ophthalmic manifestations in COVID-19 and the diagnostic value of ocular tissue/fluid. Graefes Arch Clin Exp Ophthalmol. 2020;258:1351-1352. doi:10.1007/ s00417-020-04695-8

24. Zhou Y, Duan C, Zeng Y, et al. Ocular findings and proportion with conjunctival SARS-COV-2 in COVID-19 patients. Ophthalmology. 2020. doi:10.1016/j.ophtha.2020.04.028

25. Deng W, Bao L, Gao H, et al. Ocular conjunctival inoculation of SARS-CoV-2 can cause mild COVID-19 in rhesus macaques. bioRxiv. 2020. doi:10.1101/2020.03.13.990036

26. Güemes-Villahoz N, Burgos-Blasco B, Vidal-Villegas B, et al. Novel insights into the transmission of SARS-CoV-2 through the ocular surface and its detection in tears and conjunctival secretions: a review. Adv Ther. 2020;37(10):4086-4095. doi:10.1007/s12325-02001442-7

27. Napoli PE, Nioi M, d'Aloja E, Fossarello M. The ocular surface and the coronavirus disease 2019: does a dual 'ocular route' exist? J Clin Med. 2020;9(5):1269. doi:10.3390/jcm9051269

28. Napoli PE, Nioi M, d'Aloja E, Fossarello M. Safety recommendations and medical liability in ocular surgery during the COVID-19 pandemic: an unsolved dilemma. J Clin Med. 2020;9(5):1403. doi: $10.3390 /$ jcm 9051403

\section{Dovepress}

\section{Publish your work in this journal}

Clinical Ophthalmology is an international, peer-reviewed journal covering all subspecialties within ophthalmology. Key topics include: Optometry; Visual science; Pharmacology and drug therapy in eye diseases; Basic Sciences; Primary and Secondary eye care; Patient Safety and Quality of Care Improvements. This journal is indexed on PubMed

Central and CAS, and is the official journal of The Society of Clinical Ophthalmology (SCO). The manuscript management system is completely online and includes a very quick and fair peer-review system, which is all easy to use. Visit http://www.dovepress.com/ testimonials.php to read real quotes from published authors. 